\title{
Gambaran Faktor Konsumsi Tablet Tambah Darah Pada Remaja Putri
}

\author{
Overview Factors Of Consumption Of Blood Added Tablets In \\ Female Adolescent
}

\author{
Susi Irianti ${ }^{1}$, Sahiroh \\ STIKES Faletehan, Serang, Banten \\ ${ }^{1}$ Email: iriantisusi85@yahoo.co.id
}

\begin{abstract}
ABSTRAK
Remaja adalah periode yang dianggap rentan dari sudut pandang gizi karena beberapa alasan. Pertama, dari sisi bertambahnya kebutuhan zat gizi karena pertumbuhan dan perkembangan fisik yang sangat cepat. Salah satu masalah gizi dan kesehatan remaja putri adalah anemia. Tujuan penelitian ini untuk mengetahui gambaran faktor konsumsi tablet tambah darah pada remaja putri kelas VIII di SMP Negri 1 Ciruas Tahun 2019. Jenis Penelitian deskriptif, teknik pengambilan sampel simple random sampling sebanyak 100 responden. Hasil penelitian remaja putri yang konsumsi tablet tambah darah 80 orangg $80 \%$, dan, sikap positif 87 orang (87\%), mendapatkan dukungan guru 69 orang (69\%), mendapatkan dukungan orang tua 73 orang $(73 \%)$.
\end{abstract}

Kata Kunci: Anemia, Fe, Tablet Tambah Darah

\section{ABSTRACT}

Teenagers are periods that are considered vulnerable from a nutritional perspective for several reasons. First, in terms of increasing the need for nutrients because of physical growth and rapid development. One of the problems of nutrition and health of young women is anemia. The purpose of this study was to determine the picture of the factors that consume blood-added tablets in Class VIII female adolescents in junior high school 1 Ciruas in 2019. The type of research was descriptive, the simple random sampling technique was 100 respondents. The results of the study of young women who consumed tablets plus 80 people $80 \%$, and, positive attitudes 87 people (87\%), received teacher support 69 people (69\%), received support from parents of 73 people (73\%).

Keywords:Anemia, Fe, Blood Added Tablets

\section{PENDAHULUAN}

Remaja merupakan masa yang rentan dari sudut pandang gizi. Pertambahan kebutuhan zat gizi karena pertumbuhan dan perkembangan fisikyang cepat dan perubahan gaya hidup serta kebiasaan makanan mempengaruhi kebutuhan an asupan gizi. Salah satu masalah gizi pada remaja putri Anemia merupakan salah satu masalah gizi dan kesehatan pada remaja putri. Anemia merupakan masa sel darah merah atau konsentrasi hemoglobin $(\mathrm{Hb})$ yang mengakibatkan turunnya kemampuan arah untuk mengangkut oksigen. (Departemen Kesehatan RI, 2008).

Anemia defisiensi besi adalah anemia yang lebih sering ditemukan pada remaja, karena kebutuhan zat besi 
yang tinggi untuk pertumbuhan. Berdasarkan data hasil Riskesdas tahun 2013, prevalensi anemia pada kelompok remaja usia 15-24 tahun mencapai $18,4 \%$. Kurangnya asupan gizi makro seperti karbohidrat, protein, lemak dan kekurangan zat gizi mikro seperti vitamin dan mineral.

Hal ini sebagaimana penelitian Hamidiyah, dkk (2019) menunjukkan bahwa faktor determinan penyebab anemia tertinggi adalah konsumsi gizi tidak sesuai AKG sebesar 94\%. Selain itu, saat menstruasi menjadi penyebab remaja puteri menjadi rentan terhadap anemia. Zat besi sangat dibutuhkan untuk pembentukan darah dalam mensintesa hemoglobin. Hal ini terjadi karena mentruasi yang dialami oleh remaja putri setiap bulannya yang berdampak kekurangan zat besi dalam darah.

Pemerintah meluncurkan program pemberian suplemen zat besi atau tablet tambah darah (TTD) untuk remaja putri agar dapat berkontribusi memutus lingkaran malnutrisi antargenerasi (WHO 2005). Pemerintah menyatakan bahwa pemberian TTD dengan komposisi terdiri dari $60 \mathrm{mg}$ zat besi elemental (dalam bentuk sediaan Ferro sulfat, Ferro Glukonat) dan 0,400 mg asam folat pada remaja putri usia 1218 tahun dan Wanita Usia Subur (WUS). Zat besi diperlukan untuk pembentukan darah dan juga diperlukan oleh berbagai dalam enzim juga diperlukan untuk mengangkut elektro (sitokrom), untuk mengaktifkan oksigen, sehingga bila kadar zat besi kurang maka tidak ada yang mengikat hemoglobin dalam darah dan terjadi pengurangan kadar $\mathrm{Hb}$ dalam darah yang disebut anemia.

Zat besi yang diberikan secara oral adalah salah satu cara untuk pencegahan dan pengendalian anemia yang diberikan pada remaja putri sebanyak 1 tablet/minggu dan 1 tablet/hari selama 10 hari ketika mentruasi (Kemenkes, 2016).

\section{METODE PENELITIAN}

Jenis penelitian ini adalah penelitian deskriptif dengan metode kuantitatif. Populasi yang digunakan pada penelitian ini adalah remaja putri kelas VIII di SMP Negeri 1 Ciruas, periode bulan April-Mei 2018 dengan jumlah Sampel yang didapat menggunakan teknik Total sampling yaitu keseluruhan populasi diambil untuk dijadikan sampel yaitu sebanyak 100 orang. Teknik pengumpulan data 
adalah data Primer yang didapat langsung dari responden dengan memberikan kuesioner kepada satu orang dengan memberikan penjelasan terlebih dahulu dan memberikan peluang kepada responden untuk mengajukan pertanyaan jika belum memahami dalam mengisi kuesioner.

\section{HASIL DAN PEMBAHASAN}

Tabel 1. Distribusi Frekuensi Gambaran Konsumsi Tablet Tambah Darah Pada Remaja Putri

\begin{tabular}{lcc}
\hline \multicolumn{1}{c}{ Konsumsi } & $\mathbf{n}$ & $\begin{array}{c}\text { Persentase } \\
\mathbf{\%}\end{array}$ \\
\hline Konsumsi & $\mathbf{8 0}$ & $\mathbf{8 0} \%$ \\
Tidak Konsumsi & $\mathbf{2 0}$ & $\mathbf{2 0} \%$ \\
\multicolumn{1}{c}{ Jumlah } & $\mathbf{1 0 0}$ & $\mathbf{1 0 0} \%$ \\
\hline
\end{tabular}

Berdasarkan tabel 1 diatas, diketahui dari 100 responden,sebagian besar Remaja Putri mekonsumsi Tablet Tambah Darah yang di berikan sebesar 80 (80\%), sedangkan yang tidak mengonsumsi sebesar 20 (20\%).

Tabel 2. Distribusi Frekuensi Gambaran Sikap Konsumsi Tablet Tambah Darah Pada Remaja Putri

\begin{tabular}{lcc}
\hline \multicolumn{1}{c}{ Sikap } & n & $\begin{array}{c}\text { Persentase } \\
\text { \% }\end{array}$ \\
\hline Positif & $\mathbf{8 7}$ & $\mathbf{8 7} \%$ \\
Negative & $\mathbf{1 3}$ & $\mathbf{1 3} \%$ \\
Jumlah & $\mathbf{1 0 0}$ & $\mathbf{1 0 0 \%}$ \\
\hline
\end{tabular}

Berdasarkan tabel 2 diatas, diketahui dari 100 responden,sebagian besar memiliki sikap positif pada kepatuhan konsumsi tablet tambah darah sebanyak 87 responden $(87 \%)$, sedangkan yang negatif sebesar 13 responden (13\%).

Diketahui bahwa dari 100 responden memiliki sikap negatif terhadap konsumsi tablet tambah darah sebanyak 87 responden (87\%). Dan dan diantara yang tidak baik terdapat 13 responden $(13 \%)$ memiliki sikap yang tidak baik tentang konsumsi tablet tambah darah. Penyebab sikap remaja putri yang tidak mengonsumsi tablet tambah darah yaitu kurangnya minat remaja putri dalam mengonsumsi tambet tambah darah dikarenakan tidak merasakan perubahan didalam dirinya dan rasa tablet tambah darah yang berbau amis. Terdapat faktor yang memiliki hubungan dengan konsumsi tablet tambah darah yaitu kurang dapat diterimanya rasa tablet tambah darah menjadi salah satu faktor yang dapat mempengaruhi kepatuhan dalam mengonsumsi tablet tambah darah.

Adapun yang menyebutkan bahwa hasil penelitian Budiari dan Subagio (2012), sebesar 48,2\% subjek tidak mengonsumsi tablet tambah darah karena rasa yang tidak enak dan bau amis.

Sikap merupakan kesiapan pada individu seseorangdalam melakukan tindakan tertentu terhadap suatu hal. 
Sikap ini bisa bersifat positif maupun negatif. sikap positif cenderung melakukan pendekatan, senang, berharap akan obyek tertentu. Sedangkan sikap negatif, kecenderungan tindakan adalah membenci, tidak suka terhadap obyek tertentu. (Edwars dalam Azwar, 2013).

Tabel 3. Distribusi Frekuensi Gambaran Dukungan Guru Terhadap Konsumsi Tablet Tambah Darah Pada Remaja Putri

\begin{tabular}{lcc}
\hline \multicolumn{1}{c}{ Dukungan guru } & n & $\begin{array}{c}\text { Persentase } \\
\text { \% }\end{array}$ \\
\hline Mendukung & $\mathbf{6 9}$ & $\mathbf{6 9 \%}$ \\
Kurang mendukung & $\mathbf{3 1}$ & $\mathbf{3 1 \%}$ \\
Jumlah & $\mathbf{1 0 0}$ & $\mathbf{1 0 0 \%}$ \\
\hline
\end{tabular}

Berdasarkan tabel 3 diatas, diketahui dari 100 responden, sebagian besar Guru mendukung dalam pemberian Tablet Tambah Darah sebesar 69 (69\%), sedangkan yang tidak mendukung sebesar 31 (31\%).

Sebagian besar Guru mendukung dalam pemberian Tablet Tambah Darah sebesar 69 (69\%) Dan diantara yang tidak mendukung terdapat 31 responden (31\%) yang merasa mendapatkan dukungan dari guru terhadap mengonsumsi tablet tambah darah pada remaja putri. Dukungan guru sangat berperan penting terhadap remaja putri untuk mengonsumsi tablet tambah darah, pendekatan yang baik dapat dilakukan oleh guru terhadap remaja putri sehingga hanya sebagian kecil yang tidak mengonsumsi tablet tambah darah, akan tetapi alasan lain seperti pola pikir bahwa mereka tidak memerlukan untuk meminum tablet tambah darah karena merasa tidak sakit. Selain itu sebagian besar waktu yang dihabiskan oleh remaja putri setiap harinya disekolah dibandingkan dirumah membuat peran guru sangat penting untuk membuat remaja putri patuh mengonsumsi tablet tambah darah.

Tabel 4. Distribusi Frekuensi Gambaran Dukungan Orang Tua Terhadap Konsumsi Tablet Tambah Darah Pada Remaja Putri

\begin{tabular}{ccc}
\hline $\begin{array}{c}\text { Dukungan Orang } \\
\text { Tua }\end{array}$ & n & $\begin{array}{c}\text { Persentase } \\
\text { \% }\end{array}$ \\
\hline Mendukung & $\mathbf{7 3}$ & $\mathbf{7 3} \%$ \\
Tidak Mendukung & $\mathbf{2 7}$ & $\mathbf{2 7} \%$ \\
Jumlah & $\mathbf{1 0 0}$ & $\mathbf{1 0 0 \%}$ \\
\hline
\end{tabular}

Berdasarkan tabel 4 diatas, diketahui dari 100 responden,sebagian besar Orang Tua mendukung dalam pemberian Tablet Tambah Darah sebesar 73 (73\%), sedangkan yang tidak mendukung sebesar 27 (27\%).

Sebagian besar Orang Tua mendukung dalam pemberian Tablet Tambah Darah sebesar 73 (73\%) dan diantaranya yang kurang mendukung terdapat 27 responden (27\%), yang merasa mendapatkan dukungan dari orang tua terhadap mengonsumsi tablet 
tambah darah pada remaja putri. Dukungan orang tua sangat berperan penting dan salah satu cara pendekatan yang baik dapat dilakukan dengan mendukung dan mengingatkan remaja putri untuk mengonsumsi tablet tambah darah.

Sesuai dengan hasil penelitian Albery (2011), dukungan keluarga menjadi faktor yang diperlukan untuk membentuk niat para remaja putri dalam mengonsumsi tablet tambah darah untuk mencegah anemia. Dengan tingginya dukungan yang diberikan oleh keluarga maka akan terbentuk suatu keyakinan normatif dan remaja putri akan cenderung membentuk presepsi positif terhadap konsumsi tablet tambah darah, untuk membentuk suatu niat yang kuat untuk mengonsumsi tablet tambah darah agar terhindar dari resiko anemia.

Menurut Kozier (2010), bahwa keluarga biasanya akan menurunkan pola perilaku, kebiasaan, dan gaya hidup kepada generasi berikutnya, termasuk dalam mempengaruhi kesehatan anggota keluarganya. Selain itu salah satu fungsi keluarga adalah untuk mempertahankan keadaan kesehatan anggota keluarganya agar tetap memiliki produktivitas yang tinggi.
Pembentukan niat menjadi suatu tindakan diperoleh dari pengolahan niat melalui seberapa penuh keyakinan seseorang untuk melakukan perilaku tersebut. Keyakinan ini disebut sebagai keyakinan normative, yaitu keyakinan yang didukung oleh orang-orang yang kita anggap penting seperti keluarga yang menginginkan kita untuk melakukan perilaku tersebut. Oleh karena itu terbentuknya niat remaja putri yang kuatdalammengonsumsi tablet tambah darah diperlukan adanya pengaruh sosial dan dukungan dari keluarga.

\section{SIMPULAN DAN SARAN}

Sebagian besar remaja putri kelas VIII di SMP Negeri Ciruas sudah mengkonsumsi tablet Fe dan bersikap positif terhadap pemberian tablet $\mathrm{Fe}$. Dukungan guru dan orang tua sebagian besar sudah mendukung program pemberian tablet Fe. Diharapkan untuk pihak sekolah dapat terus mengingatkan siswinya setiap bulan dan mendukung pihak puskemas dalam menjalankan program pemberian tablet Fe.

\section{DAFTAR PUSTAKA}

Albery. 2011. Psikologi Kesehatan Panduan Lengkap dan Komprehensif Bagi Studi 
Psikologi Kesehatan. Jakarta: Palmal.

Azwar. 2013.Sikap Manusia: Teori dan Pengukurannya. Yogyakarta: Pustaka Pelajar

Budiarni W, Subagio HW. 2012. Hubungan pengetahuan, sikap, dan motivasi dengan Kepatuhan konsumsi tablet besi folat pada ibu hamil. Journal of Nutrition College 1(1):99-106

Departemen Kesehatan RI. 2008. Program Penanggulangan Anemia Gizi pada Wanita Usia Subur (WUS), Jakarta: Departemen Kesehatan.

Hamidiyah, A., Rohmani, L., Zahro, N.A., 2019. Faktor Determinan Anemia Santri Putri. Oksitosin: Jurnal Ilmiah Kebidanan. Vol.6 (1).P:64-72. https://journal.ibrahimy.ac.id/ind ex.php/oksitosin/article/view/345 1334

Kemenkes RI. 2015. Laporan akuntabilitas kinerja tahun 2015. Jakarta: ditjen bina Gizi dan KIA, kementerian kesehatan

Kozier, B. 2010. Buku Ajar Fundamental Keperawatan Konsep Proses dan Praktik. Edisi VII. Volume I. Jakarta:EGC

WHO. 2005. Nutrition in adolescent: issues and challenges for the health sector: issues in adolescent health and development. WHOdiscussion paperson adolescent. Geneva: WHO

http://apps.who.int/iris/bitstream/ 1065/43342/1/9241593660_eng.p df. 